\title{
Microbial Targeting of ${ }^{99 m}$ Tc-Labeled Recombinant Human $\beta$-Defensin-3 in an Animal Model of Infection: A Feasibility Pilot Study
}

\author{
Mauro Liberatore ${ }^{1}$, Alessandro Pala ${ }^{2}$, Sergio Scaccianoce ${ }^{3}$, Christos Anagnostou ${ }^{1}$, Ugo Di Tondo ${ }^{4}$, Enrico Calandri ${ }^{1}$, \\ Piera D'Elia ${ }^{2}$, Milton D. Gross ${ }^{5}$, and Domenico Rubello 6 \\ ${ }^{I}$ Nuclear Medicine Unit, Department of Radiological Sciences, "La Sapienza" Rome University, Rome, Italy; ${ }^{2}$ Perinatology and \\ Puericulture Unit, Laboratory of Biochemistry of Sex Hormones, Department of Gynaecological Sciences, "La Sapienza” Rome \\ University, Rome, Italy; ${ }^{3}$ Department of Human Physiology and Pharmacology, "La Sapienza” Rome University, Rome, Italy; \\ ${ }^{4}$ Department of Experimental Medicine and Pathology, "La Sapienza” Rome University, Rome, Italy; ${ }^{5}$ Nuclear Medicine Service, \\ Department of Veteran Affairs Health System, Ann Arbor, Michigan; and ${ }^{6}$ Department of Nuclear Medicine, "S. Maria della \\ Misericordia" Hospital, Rovigo, Italy
}

Human $\beta$-defensin-3 (HBD-3) is an antimicrobial peptide with bactericidal effects on many gram-positive and gram-negative bacteria and some yeast species and, if radiolabeled, might be used to distinguish bacterial infection from sterile inflammation. The goals of the present study were to develop methods for radiolabeling HBD-3 with $99 \mathrm{mTC}$ and to perform preliminary investigations on $99 \mathrm{~m}$ Tc-labeled HBD-3 as a means to evaluate induced infection in an animal model. To this purpose, Staphylococcus aureus-induced infection was used to evaluate the capability of $99 \mathrm{mTc}-\mathrm{HBD}-3$ to distinguish infection from aseptic inflammation in rats. Methods: Twenty to $40 \mu \mathrm{g}$ of recombi-

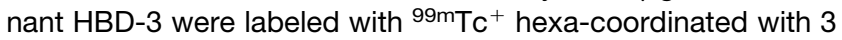
molecules of $\mathrm{CO}$ and $\mathrm{H}_{2} \mathrm{O}$ and separated by a column from free ${ }^{99 m}$ Tc. ${ }^{99 m}$ Tc-HBD-3 was added to cultures of a bacterial suspension of $S$. aureus and Escherichia coli to evaluate in vitro antibacterial activity. A bacterial suspension of $S$. aureus and a carrageenan solution were used to induce infection and sterile inflammation, respectively, in opposite thighs of 9 adult rats. Three separate experiments were performed on groups of 3 rats each. The animals received different doses of ${ }^{99 m T c-H B D}-3$ injected through a cannula into the jugular vein. After sacrifice of the animals, tissue samples were obtained from sites of infection, inflammation, and control muscle (left foreleg) at 1, 3, and $5 \mathrm{~h}$ after ${ }^{99 \mathrm{~m} T \mathrm{~T}-\mathrm{HBD}-3}$ administration. Tissue samples were weighed and then counted in a well-counter. Simultaneously,

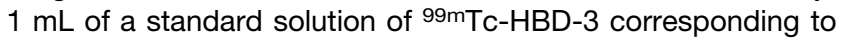
each administered dose was counted. Results: $99 \mathrm{~m}$ Tc-HBD-3 retained antibacterial activity. Radioactivity in tissue samples from the infected sites was significantly higher than that in samples of either induced inflammation or normal control muscle (ratio, $\sim 3: 1$ ) at 3 and $5 \mathrm{~h}$ after injection, whereas similar radioactivity counts were observed for tissue samples from aseptic inflammation sites and normal control muscle. Conclusion: In this inves-

Received Jun. 30, 2008; revision accepted Sep. 22, 2008.

For correspondence or reprints contact: Domenico Rubello, Department of Nuclear Medicine, PET Center, "S. Maria della Misericordia" Hospital,

V. le Tre Martiri 140, 45100 Rovigo, Italy.

E-mail: domenico.rubello@libero.it

COPYRIGHT @ 2009 by the Society of Nuclear Medicine, Inc. tigation, 99mTc-HBD-3 retained antibacterial activity and successfully distinguished infection from aseptic inflammation in adult rats.

Key Words: infection; inflammation; antimicrobial cationic peptides; peptide imaging; adult rats

J Nucl Med 2009; 50:823-826

DOI: 10.2967/jnumed.108.055533

I the last $20 \mathrm{y}$, several radiopharmaceuticals have been developed to localize infection and inflammation (1). Of the currently available scintigraphic techniques, ${ }^{111} \mathrm{In}$ or ${ }^{99 \mathrm{~m}} \mathrm{Tc}$ labeled leukocyte scintigraphy is considered worldwide as the gold standard for the evaluation of infection because the technique reaches, for some indications, high values of sensitivity and specificity ( $90 \%)$. However, like other radiopharmaceuticals, such as ${ }^{67} \mathrm{Ga}$-citrate, labeled $\mathrm{IgG}$, ${ }^{99 \mathrm{~m}} \mathrm{Tc}$-labeled ciprofloxacin, and ${ }^{18} \mathrm{~F}-\mathrm{FDG}$, false-positive results may occur also with leukocyte scintigraphy, and in some cases a definitely differential diagnosis between infection and aseptic inflammation cannot be reached (1).

Because some antimicrobial peptides selectively bind to the bacterial cell membrane, they have recently been investigated; preliminary data have suggested that they have the potential of distinguishing infection from aseptic inflammation. Among them, mammalian defensins are antimicrobial peptides of 30-40 amino acids with a molecular weight of approximately $3-4 \mathrm{kDa}(2,3)$. Human $\alpha$-defensins are found within neutrophils and Paneth cells (3), whereas $\beta$-defensins are expressed by epithelial tissues. Defensins would function as a first line of defense between an organism and the environment (4). Human $\beta$-defensin-3 (HBD-3) is a $4-\mathrm{kDa}$ antimicrobial peptide with broad activity against many 
gram-positive and -negative bacteria and some yeast species (5-7).

In the present feasibility pilot study, we evaluated methods to radiolabel HBD-3 with ${ }^{99 \mathrm{~m}} \mathrm{Tc}$. We also evaluated the in vitro antimicrobial effect of ${ }^{99 \mathrm{~m} T c-H B D}-3$ in an animal model with the goal of assessing the potential of ${ }^{99 \mathrm{~m}} \mathrm{Tc}-$ HBD-3 as a radiopharmaceutical for imaging infection.

\section{MATERIALS AND METHODS}

\section{Radiolabeling of HBD-3}

Recombinant HBD-3 (Alpha Diagnostics) was labeled through the cationic complex $\left.{ }^{99 \mathrm{~m}} \mathrm{Tc}\left(\mathrm{H}_{2} \mathrm{O}\right)_{3}(\mathrm{CO})_{3}\right]^{+}$, which can be synthesized from a commercial kit formulation (Isolink; Mallinckrodt Medical BV) based on direct reduction of ${ }^{99} \mathrm{mcO}_{4}{ }^{-}$ with sodium borohydride in aqueous solution in the presence of carbon monoxide (8). One milliliter of water containing ${ }^{99 \mathrm{~m}} \mathrm{TcO}_{4}{ }^{-}$ (as salt, 74-148 MBq) was added to the Isolink vial, and the reaction mixture was heated at $100^{\circ} \mathrm{C}$ for $20 \mathrm{~min}$ to synthesize the intermediate $\left[{ }^{99 \mathrm{~m}} \mathrm{Tc}\left(\mathrm{H}_{2} \mathrm{O}\right)_{3}(\mathrm{CO})_{3}\right]^{+}$. After cooling to room temperature, the solution was brought to $\mathrm{pH} 8.0$ with $0.5 \mathrm{M}$ $\mathrm{HCl}$. Three hundred microliters of water solution containing 20 $40 \mu \mathrm{g}$ of peptide were added to the vial, and the mixture was left to react at room temperature for $60 \mathrm{~min}$. The labeled HBD-3 was liberated from salts and inorganic ${ }^{99 \mathrm{~m}} \mathrm{Tc}$ by gel chromatography through a Sephadex G-25 disposable column (PD-10; GE Healthcare-Europe) equilibrated and eluted in physiologic saline. Protein concentrations of 1-mL fractions were assessed by the Bradford dye binding method (9). Aliquots consisting of $1 \mathrm{~mL}$ of the eluted solution were counted with a radioactivity well-counter, and radiolabeling yields and specific activities of the compound were calculated.

\section{Antimicrobial Testing of Labeled HBD-3}

Bacterial suspensions were prepared and the antimicrobial activity tests performed as previously described by Harwig et al. (10). ${ }^{99 \mathrm{~m} T c-H B D-3}$ solution at a concentration of $2.5-5 \mu \mathrm{g} / \mathrm{mL}$ was added to cultures of Staphylococcus aureus and Escherichia coli suspensions with a final concentration of $7-9 \cdot 10^{5}$ colonyforming units $/ \mathrm{mL}$ in a volume of $100 \mu \mathrm{L}$ of $10 \mathrm{mM}$ phosphate buffer solution with $1 \%(\mathrm{v} / \mathrm{v})$ trypticase soy broth (Oxoid S.p.A.; Garbagnate Milanese). The reaction lasted $2 \mathrm{~h}$ in a $37^{\circ} \mathrm{C}$ water bath before dilution with $1,900 \mu \mathrm{L}$ of ice-cold $0.15 \mathrm{M} \mathrm{NaCl}$ solution. A 10-fold dilution sample in $10 \mathrm{mM}$ phosphate buffer and negative control, containing physiologic saline instead of HBD-3, was also prepared. Twenty-microliter aliquots of each sample were spread over the surface of duplicate plates of trypticase soy agar. The plates were incubated at $37^{\circ} \mathrm{C}$ per $24 \mathrm{~h}$ and counted when their content did not exceed 800 colonyforming units per plate. The mean number of colonies per plate multiplied by 1,000 or 10,000 allowed the evaluation of colonyforming units $/ \mathrm{mL}$ in the original $100-\mu \mathrm{L}$ incubation mixture.

\section{Animal Studies}

Male 2-mo-old Wistar rats, weighing 150-200 g (Harlan Nossan), were housed in a temperature-controlled $\left(21^{\circ} \mathrm{C} \pm 1{ }^{\circ} \mathrm{C}\right)$ room with a 12-h light-dark cycle for $1 \mathrm{wk}$ before the experiments.

First Step. As previously described in the literature (11), infection was induced in the right thigh of the rat by injecting a suspension of $0.2 \mathrm{~mL}$ of $0.14 \mathrm{M} \mathrm{NaCl}$ containing $10^{6}$ colony- forming units of S. aureus (Oxoid S.p.A.; Garbagnate Milanese). After $24 \mathrm{~h}$, sterile inflammation was obtained after injection of $1 \mathrm{~mL}$ of saline solution containing $0.1 \mathrm{~mL}$ of a $1 \%$ solution of carrageenan (Sigma Aldrich s.r.l.). Four hours later, the rat was sacrificed by $\mathrm{CO}_{2}$ asphyxiation and about $1 \mathrm{~cm}^{3}$ of tissue was extracted from the sites of infection and inflammation and from the left foreleg as a control. Tissue samples were weighed, sliced, fixed, and stained (hematoxylin-eosin) to histologically assess the severity and extent of induced lesions.

Second Step. In 9 rats, $3 \mathrm{~d}$ before tissue harvesting, a cannula was implanted in the jugular vein of the rats; $24 \mathrm{~h}$ before the experiment and on the day of the experiment, infection and sterile inflammation were induced as previously described. Three separate experiments were performed on groups of 3 rats each.

Three hours after the induction of inflammation, anesthesia with sodium pentobarbital $(5.5 \mathrm{mg} / 100 \mathrm{~g}$ of body weight $)$ was administered, and varying doses of ${ }^{99 \mathrm{~m}} \mathrm{Tc}-\mathrm{HBD}-3$ were injected through the previously implanted jugular vein cannula: 1.6, 2.5, and $3.2 \mu \mathrm{g}$ of ${ }^{99 \mathrm{~m}} \mathrm{Tc}-\mathrm{HBD}-3$ in the first group of 3 rats; $2.0,2.4$, and $3.3 \mu \mathrm{g}$ of ${ }^{99 \mathrm{~m}} \mathrm{Tc}-\mathrm{HBD}-3$ in the second group of 3 rats; and 2.0, 2.4 , and $3.0 \mu \mathrm{g}$ of ${ }^{99 \mathrm{~m}} \mathrm{Tc}-\mathrm{HBD}-3$ in the third group of 3 rats.

Doses and controls of ${ }^{99 \mathrm{~m}} \mathrm{Tc}-\mathrm{HBD}-3$ were handled in the following manner. All the syringes containing the solution to be injected were weighed; a small part of the solution of each syringe was dispensed into a Erlenmeyer $500 \mathrm{~mL}$ flask; the flask was filled with $500 \mathrm{~mL}$ with saline; each syringe containing the labeled peptide to be injected was reweighed; and after injection, the empty syringes were weighed again.

Experiments were performed in triplicate at 1,3 , and $5 \mathrm{~h}$ after ${ }^{99 m}$ Tc-HBD-3 administration. The animals were sacrificed and tissue samples obtained from sites of induced infection and inflammation and from control sites. Tissue samples were weighed and counted in a well-counter, and at the same time, $1 \mathrm{~mL}$ of the standard solution corresponding to each administered dose was also counted.

Injected dose per animal in counts per minute (cpm) was calculated by dividing the product of the weight $(\mathrm{g})$ of injected solution per radioactivity ( $\mathrm{cpm}$ ) of the flask by the weight $(\mathrm{g})$ of solution dispensed into the flask. Injected dose was used to calculate its percentage counted in each sample (\%ID) and the same number divided by the weight of the sample $(\% \mathrm{ID} / \mathrm{g}$ of tissue).

The histologic findings were evaluated in a masked fashion by 2 experienced pathologists; in cases of discrepancy, the final diagnosis was reached by consensus.

\section{RESULTS}

The recovery of peptide from column chromatography was between $60 \%$ and $70 \%$, with a radiolabeling yield that ranged from $40 \%$ to $50 \%$. The resulting specific activities were between 2 and $6 \mathrm{MBq} / \mu \mathrm{g}$. In vitro antimicrobial testing of labeled peptide found a significant reduction of growth of the 2 bacterial strains (Table 1). The dose level of ${ }^{99 \mathrm{~m} T c-H B D}-3$ used in the experiment $(3.4 \mu \mathrm{g} / \mathrm{mL})$ resulted in an inhibition of bacterial growth that was higher for S. aureus than for E. coli.

Histologic evaluation of tissues from sites of induced infection and inflammation demonstrated expected characteristic lesions as shown in Figure 1. Extensive and similar 
TABLE 1. Effect of Addition of ${ }^{99 \mathrm{mTC}-\mathrm{HBD} 3}$ on Bacterial Growth

\begin{tabular}{|c|c|c|c|c|}
\hline \multirow[b]{3}{*}{ Group } & \multicolumn{4}{|c|}{ Dilution } \\
\hline & \multicolumn{2}{|c|}{ S. aureus } & \multicolumn{2}{|c|}{ E. coli } \\
\hline & $1: 1,000$ & $1: 10,000$ & $1: 1,000$ & $1: 10,000$ \\
\hline Negative control & $>800$ & 59 & $>800$ & 130 \\
\hline 99mTc-HBD-3 & 200 & 17 & $>800$ & 80 \\
\hline
\end{tabular}

leukocyte infiltration characterizes both tissue samples taken from infection and inflammation sites. In this regard, it is well known that chemical and bacterial agents induce similar cellular responses from a morphologic point of view. The presence of bacteria at the infection site was assessed by Gram staining after examination of tissue cultures.

Table 2 reviews the ${ }^{99 m}$ Tc-HBD-3 radioactivity levels from tissue samples obtained from infection, sterile inflammation, and control sites expressed as \%ID/g of tissue in 9 rats, at 1,3 , and $5 \mathrm{~h}$ after administration. The data show an accumulation of ${ }^{99 \mathrm{~m} T c-H B D-3}$ in sites of infection at 3 and $5 \mathrm{~h}$ that was 2.54-fold higher than that in either the induced sterile inflammation sites or the control sites. The radioactivity counts in sites of induced sterile inflammation and in control sites were similar (Fig. 2).

\section{DISCUSSION}

Our feasibility pilot study aimed to investigate radiolabeled HBD-3 potential in an animal model.

The bacterial strains that we used to assess in vitro antimicrobial testing in cultures were S. aureus (Grampositive bacterium) and E. coli (Gram-negative bacterium): both have been reported to be targeted by native HBD-3
B

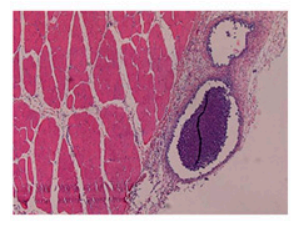

B

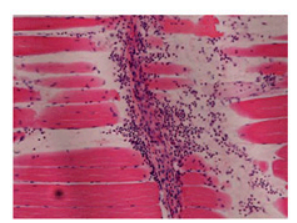

A

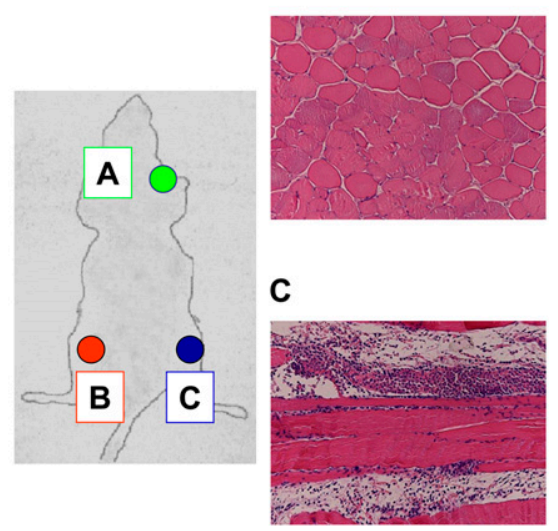

FIGURE 1. Sites of tissue sampling and relative histologic findings (hematoxylin-eosin staining): normal muscle (A), $S$. aureus-induced infection (B), and carrageenan-induced inflammation $(\mathrm{C})$. Extensive infiltration of leukocytes can be seen in $B$ and $C$, whereas presence of bacteria was demonstrated in infection site only (B) by cultural examination and Gram staining of relative sample.
TABLE 2. Accumulation of Radioactivity at Sites of Infection, Sterile Inflammation, and Normal Muscle After ${ }^{99 m T c-H B D-3}$ Administration

\begin{tabular}{lcccc}
$\begin{array}{c}\text { Rat } \\
\text { number }\end{array}$ & $\begin{array}{c}\text { Time of } \\
\text { sacrifice } \\
\text { (h) }\end{array}$ & $\begin{array}{c}\text { Muscle } \\
\text { (control } \\
\text { site) }\end{array}$ & $\begin{array}{c}\text { Sterile } \\
\text { inflammation } \\
\text { site }\end{array}$ & $\begin{array}{c}\text { Infection } \\
\text { site }\end{array}$ \\
\hline 1 & 1 & 0.039 & 0.066 & 0.055 \\
2 & 1 & 0.030 & 0.031 & 0.017 \\
3 & 1 & 0.038 & 0.095 & 0.086 \\
Mean & & 0.036 & 0.064 & 0.053 \\
4 & 3 & 0.020 & 0.020 & 0.029 \\
5 & 3 & 0.039 & 0.035 & 0.062 \\
6 & 3 & 0.045 & 0.042 & 0.150 \\
Mean & & 0.035 & 0.032 & 0.080 \\
7 & 5 & 0.022 & 0.035 & 0.053 \\
8 & 5 & 0.026 & 0.026 & 0.065 \\
9 & 5 & 0.040 & 0.038 & 0.130 \\
Mean & & 0.030 & 0.033 & 0.083 \\
\multicolumn{5}{r}{ Data are \%ID/g of tissue. } \\
\hline
\end{tabular}

$(11,12)$. Our data showed that the in vitro capability of ${ }^{99 \mathrm{~m} T c-H B D-3}$ in inhibiting bacterial growth is higher with $S$. aureus than with E. coli. Similar results have been reported using another antimicrobial peptide, the 29-41 fragment of ubiquicidin in rabbits (13). For this reason, we chose $S$. aureus for the animal investigations.

${ }^{99 m}$ Tc-labeled $\alpha$-defensin (human neutrophil peptide-1) accumulates at the site of experimentally induced $S$. aureus and $K$. pneumoniae infection in animals, but the target-tonontarget ratios are low, with a peak in uptake at $15 \mathrm{~min}$ followed by a rapid decrease within $60 \mathrm{~min}(13,14)$. By contrast, in our preliminary pilot study the target-to-nontarget ratios of ${ }^{99 \mathrm{~m} T c-H B D}-3$ were high in infection sites and increased over time, with values approaching 3.0 after 3 and $5 \mathrm{~h}$ after administration.

HBD-3 is able to kill $90 \%$ of bacteria within 2 min after its addition to bacterial cultures (15). These data are consistent with a rapid antimicrobial action of HBD-3. Conversely, our data show that in adult rats the target-tonontarget ratios between infection versus sterile inflammation and control muscle sites are similar $1 \mathrm{~h}$ after the administration of about $3.0 \mu \mathrm{g}$ of ${ }^{99 \mathrm{~m}} \mathrm{Tc}-\mathrm{HBD}-3$, whereas the target-to-nontarget ratios significantly increase to values approaching 3.0 after 3 and $5 \mathrm{~h}$ after administration. Our observations in animals may be explained by the fact that $1 \mathrm{~h}$ after ${ }^{99 \mathrm{~m}} \mathrm{Tc}-\mathrm{HBD}-3$ administration an increase in vascular permeability, blood flow, and transudation of proteins could interfere in distinguishing specific from unspecific accumulations. Instead a 3- to 5-h interval in our study appears to be more adequate to evaluate the specific binding. Therefore, one may speculate that a 3- to 5-h postadministration interval could potentially be adequate for imaging.

\section{CONCLUSION}

The present feasibility pilot study is, to our best knowledge, the first attempt to characterize ${ }^{99 \mathrm{~m} T c}$-labeled HBD-3 
FIGURE 2. Dose-dependent uptake of 99mTc-labeled HBD-3 by infection (A) and sterile inflammation (B) sites. Normal muscle (C) was used as control. Nor. $=$ normal.

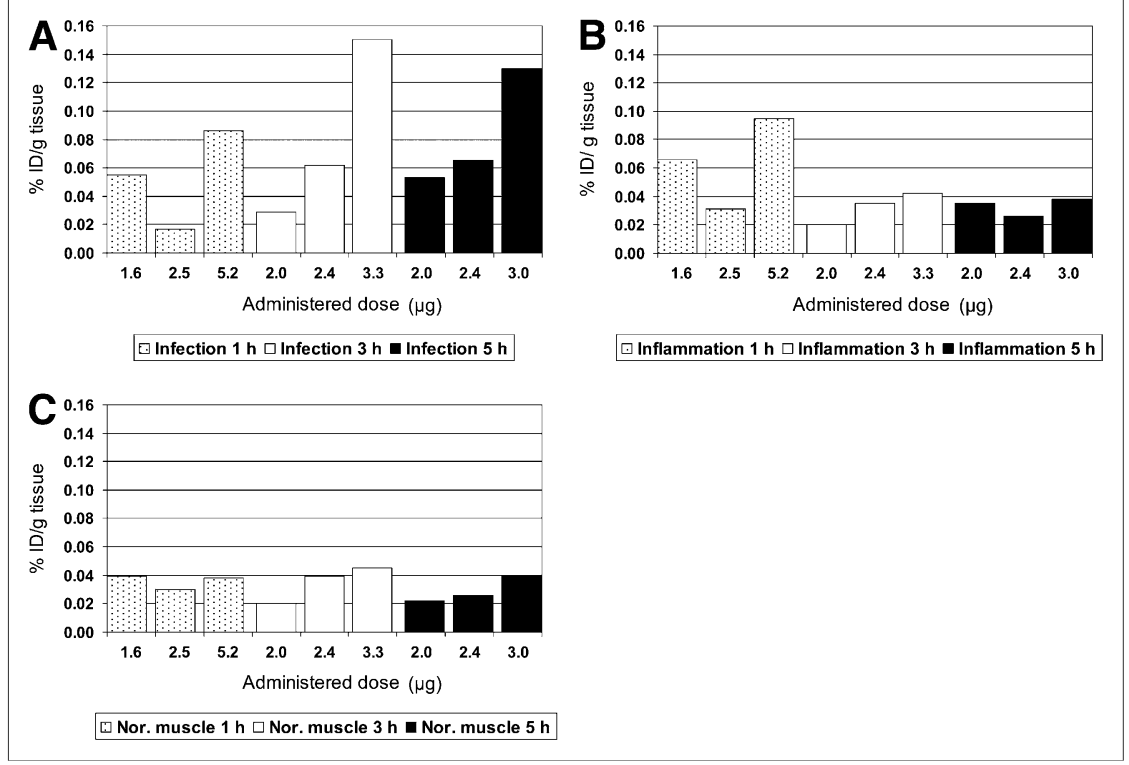

as a novel possible candidate for specific infection imaging. Although the small number of observations did not allow us to draw statistically based and definitive conclusions, 99m Tc-HBD-3 showed in vitro antimicrobial activity. In addition, in an animal model of $S$. aureus-induced infection, we observed an increase over time of the target-tonontarget ratios in infected versus noninfected tissues, with the greatest values reached $3-5 \mathrm{~h}$ after the labeled peptide administration. Subsequent experiments to assess safety, biodistribution, and dosimetry will be necessary next steps in the development of this peptide with potential for imaging infection.

\section{REFERENCES}

1. Rennen HJ, Boerman OC, Oyen WJG, Corstens FHM. Scintigraphic imaging of inflammatory processes. Med Chem Rev Online. 2004;1:27-38.

2. Ganz T, Lehrer RI. Defensins. Curr Opin Immunol. 1994;6:584-589.

3. Huttner KM, Bevins CL. Antimicrobial peptides as mediators of epithelial host defense. Pediatr Res. 1999;45:785-794.

4. Weinberg A, Krisanaprakornkit S, Dale BA. Epithelial antimicrobial peptides: review and significance for oral applications. Crit Rev Oral Biol Med. 1998;9:399-414.

5. Harder J, Bartels J, Christophers E, Schröder JM. Isolation and characterization of human $\beta$-defensin-3, a novel human inducible peptide antibiotic. J Biol Chem. 2001;276:5707-5713.
6. Garcia JR, Jaumann F, Schulz S, et al. Identification of a novel, multifunctional $\beta$-defensin (hBD-3) with specific antimicrobial activity: its interaction with plasma membranes of Xenopus oocytes and the induction of macrophage chemoattraction. Cell Tissue Res. 2001;306:257-264.

7. Jia HP, Schutte BC, Schudy A, et al. Discovery of new human beta-defensins using a genomics-based approach. Gene. 2001;263:211-218.

8. Alberto R. A novel organometallic aqua complex of technetium for labelling biomolecules: synthesis of $\left[{ }^{99 m} \mathrm{Tc}\left(\mathrm{OH}_{2}\right)_{3}(\mathrm{CO})_{3}\right]^{+}$from $\left[{ }^{99 \mathrm{~m}} \mathrm{TcO}_{4}\right]^{-}$in aqueous solution and its reaction with bifunctional ligand [abstract]. J Am Chem Soc. 1998;120:7987-7988.

9. Bradford MM. A rapid and sensitive method for the quantitation of microgram quantities of protein utilizing the principle of protein-dye binding. Anal Biochem. 1976;72:248-254.

10. Harwig SSL, Ganz T, Lehrer RI. Neutrophil defensins: purification, characterization and antimicrobial testing. Methods Enzymol. 1994;236:160-172.

11. Komarek P, Kleisner I, Komarkova I, Konopkova M. Accumulation of radiolabelled low molecular peptides and proteins in experimental inflammation. Int J Pharm. 2005;291:119-125.

12. Welling MM, Hiemstra PS, van den Barselaar MT, et al. Antibacterial activity of human neutrophil defensins in experimental infections in mice is accompanied by increased leukocyte accumulation. J Clin Invest. 1998;102:1583-1590.

13. Akhtar MS, Iqbal J, Khan MA, et al. ${ }^{99 \mathrm{~m} T c-l a b e l l e d ~ a n t i m i c r o b i a l ~ p e p t i d e ~}$ ubiquicidin (29-41) accumulates less in Escherichia coli infection than in Staphylococcus aureus infection. J Nucl Med. 2004;45:849-856.

14. Welling MM, Nibbering PH, Paulusma-Annema A, Hiemstra PS, Pauwels EK, Calame W. Imaging of bacterial infections with ${ }^{99 \mathrm{~m}} \mathrm{Tc}-$ labeled human neutrophil peptide-1. J Nucl Med. 1999;40:2073-2080.

15. Friedrich CL, Moyles D, Beveridge TJ, Hancock REW. Antibacterial action of structurally diverse cationic peptides on Gram-positive bacteria. Antimicrob Agents Chemother. 2000;44:2086-2092. 